\title{
Pengaruh Return on Equity dan Debt To Equity Ratio Terhadap Nilai Perusahaan dengan Kepemilikan Manajerial sebagai Variabel Moderasi pada Perusahaan LQ 45 yang Terdaftar di BEI Periode 2016- 2019
}

\author{
Habib Mushofa ${ }^{1}$, Aris Susetyo ${ }^{2}$ \\ 1,2 Universitas Putra Bangsa \\ habibmushofa@gmail.com ${ }^{1}$
}

\begin{tabular}{|c|c|}
\hline ARTICLE INFO & ABSTRACT \\
\hline $\begin{array}{l}\text { Keywords: } \\
\text { Return on Equity Ratio, } \\
\text { Debt to Equity Ratio, Nilai } \\
\text { Perusahaan, Kepemilikan } \\
\text { Manajerial }\end{array}$ & $\begin{array}{l}\text { Penelitian ini bertujuan untuk menguji pengaruh ROE dan DER } \\
\text { terhadap nilai perusahaan dengan kepemilikan manajerial sebagai } \\
\text { vaiabel moderasi pada perusahaan LQ } 45 \text { yang terdaftar di BEI } \\
\text { periode 2016-2019. Metode pengumpulan data menggunakan } \\
\text { purpose sampling pada perusahaan LQ } 45 \text { periode 2016-2019 hasil } \\
\text { penelitian menunjukkan bahwa ROE berpengaruh positif terhadap } \\
\text { nilai perusahaan, DER berpengaruh positif terhadap nilai } \\
\text { perusahaan, kepemilikan manajerial mampu memoderasi } \\
\text { hubungan ROE dengan nilai perusahan dan kepemilikan } \\
\text { manajerial tidak mampu memoderasi hubungan antara DER } \\
\text { dengan nilai perusahaan. }\end{array}$ \\
\hline
\end{tabular}

\section{Pendahuluan}

Semakin meningkatnya persaingan bisnis di era globalisasi saat ini tidak terlepas dari pengaruh berkembangnya lingkungan ekonomi, sosial politik, serta kemajuan teknologi. Setiap perusahaan diharapkan dapat menyesuaikan diri serta mampu membaca situasi yang terjadi agar dapat mengelola fungsi-fungsi manajemen dengan baik, mulai dari bidang produksi, bidang pemasaran, bidang sumber daya manusia, dan bidang keuangan sehingga perusahaan mampu lebih unggul dari para pesaingnya.

Salah satu tujuan perusahaan adalah memaksimalkan nilai perusahaan. Memaksimalkan nilai perusahaan merupakan tujuan jangka panjang perusahaan yang dapat diwujudkan dengan memaksimalkan nilai pemegang saham. Memaksimalkan nilai pemegang saham dapat diwujudkan dengan cara menarik investor menanam untuk modalnya (Afidah, 2014). Menurut Hartono (2009:124) tujuan perusahaan adalah mendapat keuntungan yang maksimal, memakmurkan para pemilik saham atau pemilik perusahaan. Nilai perusahaan maksimal terlihat pada harga sahamnya. Keuntungan saham tidak hanya untuk perusahaan itu sendiri, akan tetapi keuntungan tersebut juga dinikmati oleh investor yang menanamkan modalnya. 
Investor dalam menanamkan modalnya di pasar modal tidak hanya bertujuan untuk memperoleh keuntungan dalam jangka pendek, tetapi juga bertujuan untuk jangka panjang. Nilai perusahaan merupakan harga jual perusahaan yang dianggap layak oleh calon investor, jika suatu perusahaan akan dijual. Bagi perusahaan yang akan menjual sahamnya ke masyarakat (go public), indikator nilai perusahaan adalah harga saham yang diperjualbelikan dibursa efek.

Salah satu index harga saham yang terdaftar di Bursa Efek Indonesia adalah LQ 45. Index LQ 45 menggunakan 45 perusahaan yang mempunyai likuiditas tertinggi pada periode tertentu. Adanya tingkat likuiditas yang tinggi dapat memungkinkan investor untuk melakukan investasi karena dengan saham yang likuid kemungkinan mengalami kerugiannya menjadi lebih kecil. Tidak hanya dengan likuiditas yang tinggi, saham-saham yang menjadi bagian LQ 45 juga memiliki kapitalisasi pasar yang besar serta terdapat beberapa hal yang layak diperhitungkan seperti nilai transaksi, jumlah hari perdagangan, frekuensi transaksi saham dan juga kondisi keuangan yang baik.

Pada penutupan bursa akhir tahun 2019 kinerja indeks LQ45 yang terdiri dari 45 emiten mengalami kenaikan likuiditas yang tinggi. Kenaikan likuiditas ini disertai dengan penguatan kapitalisasi pasar yang cukup besar hingga mencapai titik 1,52\%. Tingginya nilai likuiditas menunjukkan bahwa perusahaan mampu melunasi hutang jangka pendeknya. Pendapatan yang tinggi dan keadaan perusahaan yang likuid akan meningkatkan nilai perusahaan, sehingga hal tersebut mampu untuk menarik daya beli para investor untuk menanamkan modalnya pada perusahaan tersebut.

Namun ada beberapa perusahaan yang tergabung tetapi mengalami penurunan saham hingga 30\%. Diantaranya, PT Hanjaya Mandala Sampoerna Tbk (HMSP), PT Indo Tambangraya (ITMG), PT Bukit Asam Tbk (PTBA), PT Gudang Garam Tbk (GGRM), PT Matahari Department Stoe Tbk (LPPF), PT Indah Kiat Pulp and Paper Tbk (INKP). Turunnya beberapa saham pada perusahaan-perusahaan tersebut akan mengakibatkan respon negatif dengan penjualan saham karena laba perusahaan kemungkinan besar mengalami penurunan.

Hal yang seharusnya terjadi adalah apabila likuiditas perusahaan baik akan berdampak pula pada peningkatan laba bersih. Laba bersih yang tinggi dapat meningkatkan nilai perusahaan yang diukur dengan harga saham. Namun, kasus di atas menunjukkan bahwa perusahaan yang laba bersihya tinggi justru mengalami penurunan harga saham. Terkait dengan naik turunnya nilai perusahaan maka nilai perusahaan menjadi aspek yang sangat penting untuk dipertahankan. Hal tersebut dikarenakan dengan tingginya harga saham yang diperjualbelikan maka nilai perusahaan juga semakin tinggi dan diharapkan akan mensejahterakan para pemegang sahamnya, sebaliknya jika nilai perusahaan menurun maka kesejahteraan pemegang saham juga menurun yang tentunya akan mempengaruhi keberlangsungan bisnis dimasa mendatang.

Penelitian ini menggunakan rasio $P B V$ sebagai indikator dalam penilaian nilai perusahaan. Menurut (Hery, 2017:6) price to book value adalah rasio perbandingan harga saham dan nilai buku ekuitas perusahaan, yang mengukur nilai yang diberikan pasar kepada manajemen dan organisasi sebagai sebuah perusahaan yang terus tumbuh. 
Nilai perusahaan dapat pula dipengaruhi oleh besar kecilnya profitabilitas yang dihasilkan oleh perusahaan. Kondisi suatu perusahaan dapat diketahui kekuatan dan kelemahannya melalui rasio profitabilitas. Jika kondisi perusahaan dikategorikan menguntungkan atau menjanjikan keuntungan dimasa mendatang maka banyak investor yang akan menanamkan dananya untuk membeli saham diperusahaan tersebut. Hal ini tentu saja mendorong harga saham naik sehingga mencerminkan nilai perusahaan yang baik. Profitabilitas merupakan tingkat keuntungan bersih yang mampu diraih oleh perusahaan pada saat menjalankan operasinya. Keuntungan yang akan dibagikan kepada pemegang saham adalah keuntungan setelah bunga dan pajak. Rasio profitabilitas digunakan untuk mengukur kemampuan perusahaan dalam menghasilkan laba bersih setelah pajak berdasarkan modal sendiri (ROE). Semakin tinggi nilai ROE maka semakin baik pula kondisi perusahaan, semakin besar pula penghasilan yang diperoleh perusahaan dan akan meningkatkan pula harga saham perusahaan yang bersangkutan (Sambora dkk, 2014:2).

Struktur modal dapat dilihat melalui Debt to Equiry Ratio (DER). Debt to Equity Ratio (DER) merupakan salah satu bentuk dari rasio Leverage untuk mengukur seberapa besar kemampuan perusahaan melunasi utang dengan modal yang dimiliki (Husnan, 2009:70). Semakin besar DER maka akan semakin kecil laba yang dibagikan ke pemegang saham, sehingga dapat menurunkan harga saham yang bersangkutan. Semakin rendah tingkat DER maka kemungkinan nilai perusahaan akan semakin tinggi dan perusahaan akan mendapat kepercayaan dari investor (Sambora dkk, 2015:2)

Terdapat permasalahan lain yang ikut mempengaruhi nilai perusahaan yakni kepemilikan manajerial. Kepemilikan manajerial merupakan tingkat atau persentase kepemilikan saham perusahaan yang dimiliki oleh pihak manajemen yang secara aktif ikut dalam pengambilan keputusan dalam perusahaan meliputi dewan direksi dan dewan komisaris. Adanya kepemilikan saham yang dimiliki oleh manajemen akan menimbulkan suatu pengawasan terhadap kebijakan-kebijakan yang akan diambil oleh manajemen perusahaan. Kepemilikan manajemerial sebagai alat yang digunakan untuk mengurangi konflik keagenan antar pihak principal dan agent pada suatu perusahaan (Jensen dan Meckeling, 1976).

\section{Kajian Teori dan Telaah Literatur}

\section{Signalling Theory}

Signalling Theory atau teori signal dikembangkan pada ilmu ekonomi dan keuangan yang dilandasi pemikiran bahwa orang dalam perusahaan (insider) pada umumnya memiliki informasi lebih baik tentang perusahaan dibandingkan dengan investor luar (outsider) (Wiyono dan Kusuma, 2017:27)

\section{Agenci Theory}

Menurut Wulandari (2015:4) agency theory mendasarkan hubungan kontrak antar anggotaanggota dalam perusahaan, principal dan agen sebagai pelaku utama. Prinsipal merupakan pihak yang memberikan mandat kepada agen untuk bertindak atas nama prinsipal, sedangkan agen merupakan pihak yang diberi amanat oleh prinsipal untuk menjalankan perusahaan. Agen berkewajiban untuk mempertanggungjawabkan apa yang telah diamanatkan oleh principal. 


\section{Nilai Perusahaan}

Menurut Fuad dkk (2006:23) nilai perusahaan adalah harga jual perusahaan yang di anggap layak oleh calon investor sehingga mampu membayarnya, jika suatu perusahaan akan dijual. Nilai perusahaan sangat penting karena dengan nilai perusahaan yang tinggi akan diikuti dengan tingginya kemakmuran pemegang saham (Brigham dan Houston 2010). Variabel dependen dalam penelitian ini adalah nilai perusahaan yang diproksikan menggunakan Price to Book Value (PBV). Adapun rumus untuk mencari PBV adalah:

$$
P B V=\frac{P S}{B V S}
$$

\section{Dimana:}

Ps = Harga per lembar saham

BVS = Nilai buku perlembar saham

\section{Kepemilikan Manajerial}

Menurut Pasaribu, Topowijaya dan Sri (2016:156) kepemilikan manajerial adalah pemilik pemegang saham oleh pihak manajemen perusahaan yang secara aktif berperan dalam pengambilan keputusan perusahaan. Adapun rumusnya yaitu:

$$
K M=\frac{\text { total saham yang dimiliki manajemen }}{\text { jumlah saham yang berjalan }} \times 100 \%
$$

\section{Profitabilitas}

Profitabilitas adalah rasio untuk menilai kemampuan perusahaan dalam mencari keuntungan. Dalam Penelitian ini profitabilitas diproksikan menggunakan ROE. Return on Equity (ROE) merupakan rasio keuangan yang menunjukkan kemampuan perusahaan untuk menghasilkan laba setelah pajak dengan menggunakan modal sendiri yang dimiliki perusahaan (Sudana, 2011:23). Adapun rumus perhitungan return on equity adalah sebagai berikut:

$$
\text { ROE }=\frac{\text { laba setelah pajak }}{\text { total equitas }} \times 100 \%
$$

\section{Leverage}

leverage adalah rasio-rasio untuk mengukur sampai seberapa jauh aktiva perusahaan dibiayai dengan hutang. Salah satu alat untuk mengukur rasio leverage adalah menggunakan Debt to Equity Ratio (DER). DER dapat dihitung menggunakan rumus sebagai berikut:

$$
D E R=\frac{\text { total hutang }}{\text { total modal sendiri }} \times 100 \%
$$


Model empiris pada penelitian ini adalah sebagai berikut:

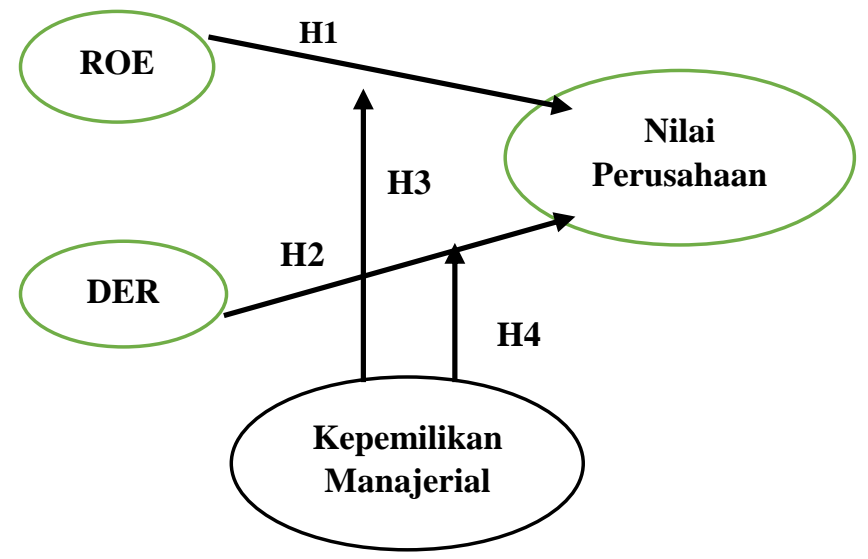

Gambar 1. Model Penelitian

\section{Metode Penelitian}

Jenis data berdasarkan sumber data tediri dari data primer dan data sekunder. Dalam penelitian ini data yng digunakan adalah data sekunder. Data yang digunakan adalah data dalam bentuk laporan tahunan. (annual report) dan ikhtisar ringkasan kinerja keuangan. Teknik pengumpulan data dalam penelitian ini adalah dengan menggunakan dokumentasi. Dokumentasi merupakan suatu metode pengumpulan data dengan cara menelaah dan mengkaji dokumen perusahaan yang berupa laporan keuangan. Studi dokumentasi dilakukan dengan mengumpulkan seluruh data sekunder dari IDX. Data dalam penelitian ini diperoleh dari laporan keuangan perusahaan.

Populasi dalam penelitian ini adalah perusahaan LQ 45 yang terdaftar di Bursa Efek Indonesia (BEI) periode 2016-2019 sebanyak 45 perusahaan. Teknik pengambilan sampel yang digunakan dalam penelitian ini adalah purposive sampling. Purposive sampling adalah suatu teknik penentuan sampel dengan pertimbangan tertentu atau seleksi khusus (Siyoto dan Sodik (2015: 66)). Pertimbangan yang digunakan untuk penentuan sampel pada penelitian ini adalah sebagai berikut: (1) Perusahaan menjadi anggota Indeks LQ 45 secara berturut-turut dari tahun 2016-2019. (2) Perusahaan yang tdakkonsaisten terabung dalam index LQ 45 secara beturu-turutperiode 2016-2019. Berdasarkan kriteria tersebut, sampel yang dihasilkan sebanyak 30 perusahaan dengan total 120 pengamatan.

\section{Hasil dan Pembahasan}

\section{Alat Analisis Data}

Analisis statistik deskriptif digunakan untuk memberikan gambaran atau deskriptif semua variabel yang digunakan agar lebih mudah dipahami. Gambaran atau deskriptif suatu data yang dilihat dari nilai rata-rata (mean), standar deviasi, mimimum,dan maximum. Variabel yang di gambarkan dalam penelitian ini adalah Nilai perusahaan, ROE, DER, dan Kepemilikan manajerial. 


\section{Uji Asumsi Klasik}

\section{Uji Normalitas}

Menurut Ghozali (2009:147) uji normalitas betujuan untuk menguji apakah dalam model regresi kedua variabel dependen maupun independen mempnyai distribusi normal atau tidak. Model regesi yang baik adalah memiliki data secara normal dengan dasar pengambilan dengan uji normalitas K-S, jika nilai signifikan lebih besar dari 0,05 maka data penelitian ini terdistribusi secara normal dan sebaliknya jia nilai signifikan kurang dari 0,05 maka data penelitian tidak normal. Penelitian ini mengunakan uji Kolmogoro-smirnov untuk menguji normalitas data.

Tabel 1. One-Sample Kolmogorov-Smirnov Test

\begin{tabular}{lll}
\hline & & $\begin{array}{l}\text { Unstandardized } \\
\text { Residual }\end{array}$ \\
\hline $\mathrm{N}$ & & 120 \\
Normal & Mean &, 0000000 \\
Parameters & Std. Deviation &, 09826724 \\
Most Extreme & Absolute &, 080 \\
Differences & Positive &, 080 \\
& Negative &,- 048 \\
Test Statistic &, 080 \\
Asymp. Sig. (2-tailed) &, $059 c$ \\
\hline \multicolumn{2}{l}{ Sumber: Data sekunder diolah (2021) }
\end{tabular}

Berdasarkan tabel 1 hasil uji normalitas Kolmogorov-smirnov test diperoleh nilai Asymp.sig.(2-tailed) sebesar 0,59 yang artinya lebih besar dari 0,05. Sehingga dapat di simpulkan bahwa data tersebut terdistribusi secara normal.

\section{Uji Multikolinearitas}

Uji multikolinearitas bertujuan untuk menguji apakah model regesi ditemukan adanya korelasi antar variabel bebas. Model regresi yan baik seharusya tidak terjadi korelasi diantara variabel independen. Jika varabel independen saling berkorelasi, maka variabelvariabel ini tidak ortogonal. Variabel ortogonal adalah variabel independen yang nilai korelasinya antar sesama variabel sama dengan nol. Untuk mendeteksi ada atau tidaknya multikolinearitas didalam model regesi dapat dideteksi dengan melihat besaran VIF dan Tolerance asumsi sebagai berikut:

a. Pedoman suatu model regresi yang tidak terjadi multikolinieritas adalah mempunyai VIF di bawah 10 dan tolerance di atas 0,1.

b. Pedoman suatu model regresi yang terjadi multikolinieritas adalah mempunyai VIF di atas 10 tolerance di bawah 0,1. 


\begin{tabular}{cccc}
\hline & & \multicolumn{2}{c}{ Collinearity } \\
\multicolumn{2}{c}{ Model } & Tolerance & VIF \\
\hline 1 & ROE &, 959 & 1,043 \\
DER &, 910 & 1,099 \\
\multicolumn{2}{c}{ KM } &, 894 & 1,119 \\
\hline \multicolumn{2}{c}{ a. Dependent Variable: PBV } \\
Sumber:Output IBM SPSS 22 diolah (2021)
\end{tabular}

Berdasarkan hasil 2 tersebut diketahiu bahwa semua variabel independen pada penelitian ini memiliki nilai tolerance lebih besar $>$ dari 0,1 dan nilai VIF kurang dari < 10. Hasil tersebut membuktikan bahwa tidak terjadi multikolinearitas dalam model regresi

\section{Uji Autokorelasi}

Uji autokorelasi bertujuan untuk menguji apakah dalam model regresi liniear ada korelasi anatara kesalahan pengganggu pada periode $t$ dengan kesalahan periode pengganggu pada periode t-1 (sebelumnya). Uji run tes adalah satu cara untuk menguji ada tidaknya autokorelasi. Uji run test sebagai bagian dari statistik non parametik dapat pula digunakan untuk menguji apakah antar residual terdapat korelasi yang tinggi, jika antar residual tidak terdapat hubungan korelasi maka dikatakan bahwa residual adalah acak atau random. Run test digunakan untuk melihat apakah data residual terjadi secara random atau tidak sistematis.

Tabel 3. Hasil uji Autokorelasi

\begin{tabular}{ll}
\hline & $\begin{array}{l}\text { Unstandardized } \\
\text { Residual }\end{array}$ \\
\hline Test Value $^{\mathrm{a}}$ &,- 00589 \\
Cases $<$ Test Value & 60 \\
Cases $>=$ Test Value & 60 \\
& 120 \\
Number of Runs & 54 \\
Z & $-1,283$ \\
Asymp. Sig. (2-tailed) &, 199 \\
\hline a. Median & \\
Sumber:Output IBM SPSS 22 diolah (2021)
\end{tabular}

Berdasarkan tabel 3 hasil uji autokorelasi runstest diperoleh nilai Asymp.sig.(2-tailed) sebesar 0,199 lebih besar > dari 0,05. Dapat disimpulkan bahwa tidak terjadi gejala atau masalah autokorelasi dalam model regresi.

\section{Uji Heteroskedastisitas}

Uji heteroskedastisitas yang dilakukan untuk menguji apakah dalam model regresi terjadi ketidakssmaan variance dari residual satu pengamatan ke pengamatan yang lain (Ghozali:2016:134). Model regresi yang baik adalah jika tidak terjadi heteroskedastisitas. Dalam penelitian ini uji heterosdkedastisitas menggunakan uji glejser. Jika nilai probabilitas signifikansi dari variable;l independen diatas tingkat kepercayaan 5\% maka dapat disimpulkan model regresi tidak mengandung adanya gejala heteroskedastisitas. 
Tabel 4. Hasil Uji Heteroskedastisitas

\begin{tabular}{cccc}
\hline \multicolumn{1}{c}{ Model } & T & Sig. \\
\hline 1 & (Constant) &, 701 &, 485 \\
& ROE & 1,580 &, 117 \\
& DER & $-1,101$ &, 273 \\
& KM &,- 244 &, 808 \\
\hline \multicolumn{2}{l}{ Sumber: Data sekunder diolah (2021) }
\end{tabular}

Bedasarkan tabel 4 masing-masing variabel independen memiliki nilai signifikan diatas 0,05. Hal ini dapat disimpulkan bahwa model regresi yang digunakan dalam penelitian ini tidak mengandung gejala heteroskedastisitas.

\section{Analisis Regresi Moderasi}

Penelitian ini menggunakan analisis residual untuk menganalisis interaksi (perkalian dua atau lebih variabel) atau pengaruh dari variabel pemoderasi (Ghozali:2011). analisis residual untuk menguji pengaruh deviasi (penyimpangan) dari suatu model. Fokusnya adalah ketidakcocokan (lack $f$ fit) yang dihasilkan dari deviasi hubungan linear antar variabel independen. Lack of fit ditunjukkan oleh nilai residual didalam regresi.

Tabel 5. Persamaan 1

\begin{tabular}{ccccccc}
\hline \multicolumn{7}{c}{ Unstandardized } \\
Coefficients & \multicolumn{2}{c}{ Standardized Coefficients } & & \\
\cline { 3 - 5 } & Model & $\mathbf{B}$ & Std. Error & Beta & $\mathbf{t}$ & Sig. \\
\hline 1 & (Constant) &, 425 &, 095 & & 4,502 &, 000 \\
& ROE &, 659 &, 055 &, 746 & 12,018 &, 000 \\
& DER &, 214 &, 065 &, 206 & 3,322 &, 001 \\
\hline
\end{tabular}

Sumber: Data Sekunder diolah (2021)

Tabel 6. Persamaan 2 Hasil uji ROE*KM

\begin{tabular}{ccccccc}
\hline & & \multicolumn{2}{c}{$\begin{array}{c}\text { Unstandardized } \\
\text { Coefficients }\end{array}$} & $\begin{array}{c}\text { Standardized } \\
\text { Coefficients }\end{array}$ & & \\
\cline { 3 - 5 } & Model & B & Std. Error & Beta & t & Sig. \\
\hline \multirow{2}{*}{1} & (Constant) &, 079 &, 086 & &, 921 &, 359 \\
& ROE &, 748 &, 061 &, 846 & 12,308 &, 000 \\
& KM &, 452 &, 112 & 2,010 & 4,027 &, 000 \\
& ROE*KM &,- 331 &, 083 & $-1,974$ & $-3,995$ &, 000 \\
\hline
\end{tabular}

Sumber: Data Sekunder diolah (2021) 
Tabel 7. Persamaan 3 Hasil uji DER*KM

\begin{tabular}{|c|c|c|c|c|c|c|}
\hline & \multirow[b]{2}{*}{ Model } & \multicolumn{2}{|c|}{$\begin{array}{l}\text { Unstandardized } \\
\text { Coefficients }\end{array}$} & \multirow{2}{*}{$\begin{array}{c}\begin{array}{c}\text { Standardized } \\
\text { Coefficients }\end{array} \\
\text { Beta } \\
\end{array}$} & \multirow[b]{2}{*}{$\mathrm{T}$} & \multirow[b]{2}{*}{ Sig. } \\
\hline & & B & Std. Error & & & \\
\hline \multirow[t]{4}{*}{1} & (Constant) & 1,350 & 112 & & 12,104 & ,000 \\
\hline & DER &,- 207 & 106 & -199 & $-1,954$ & ,053 \\
\hline & KM &,- 250 & 166 & $-1,112$ & $-1,507$ & 135 \\
\hline & $\mathrm{DER}^{*} \mathrm{KM}$ & ,228 & 173 & ,959 & 1,318 & 190 \\
\hline
\end{tabular}

Sumber: Data Sekunder diolah (2021)

PBV=0,425+0,659ROE+0,214DER+e...(1)

$\mathrm{PBV}=0,079+0,748 \mathrm{ROE}+0,452 \mathrm{KM} 0,331 \mathrm{ROE}^{*} \mathrm{KM}+\mathrm{e} \ldots \ldots .(2)$

PBV=1,350-0,207DER-0,250KM+0,228DER *KM+e.....(3)

Hasil pengujian hipotesis pertama menunjukkan nilai koefisien ROE sebesar 0,659. Nilai koefisien tersebut menunjukkan bahwa profitabilitas memiliki pengaruh positif terhadap nilai perusahaan. ROE mempunyai tingkat signifikansi sebesar 0.000 yang menunjukkan bahwa $\mathrm{p}<0,05$. Hal ini berarti hipotesis pertama dalam penelitian ini diterima. ROE berpengaruh positif dan signifikan terhadap nilai perusahaan. semakin tinggi nilai profitabilitas perusahaan maka semakin tinggi nilai perusahaannya. Perusahaan yang memiliki ROE yang tinggi memberikan sinyal positif kepada investor akan prospek perusahaan di masa yang akan datang.

Hasil pengujian hipotesis kedua menunjukkan nilai koefisien DER sebesar 0,214. Nilai koefisien tersebut menunjukkan bahwa DER memiliki pengaruh positif terhadap nilai perusahaan. DER mempunyai tingkat signifikansi sebesar 0.001 yang menunjukkan bahwa $p$ $<0,05$. Hal ini berarti hipotesis kedua dalam penelitian ini diterima. semakin besar nilai DER maka akan semakin kecil laba yang akan dibagikan kepada pemegang saham, sehingga dapat menurunkan harga saham yang bersangkutan. Hasil penelitian ini sesuai dengan teory MM dengan pajak dimana struktur modal mempengaruhi nilai perusahaan. Perusahan dengan hutang yang tinggi mendapatkan penghematan pajak dari bunga yang dibayarkan sehingga nilai perusahaannya tinggi.

Hasil pengujian hipotesis ketiga menunjukkan hasil uji interaksi antara variabel ROE dengan kepemilikan manajerial sebesar $0.000<0,005$ dan variabel pemoderasi memiliki arah negatif dilihat dari nilai koefisiennya -0.331 . Variabel kepemilikan manajerial dapat memoderasi hubungan antara ROE terhadap nilai perusahaan dengan arah negatif. Pengaruh negatif ini menunjukan adanya kekhawatiran investor dengan tindakan manajemen yang opportunistik yang cenderung mengambil keputusan untuk kepentingan sendiri.

Hasil hipotesis keempat menunjukan hasil uji interaksi antara variabel DER dengan kepemilikan manajerial sebesar 0,228 dan variabel moderasi memilikin nilai koefisien 0.190 > 0,05 sehingga menunjukan kepemilikan manajerial tidak mampu memoderasi hubungan antara DER dengan nilai perusahaan. Dengan kepemilikan manjerial yang relative rendah menyebabkan pihak manajemen tidak mempunyai wewenang penuh atas perusahaan. Sehingga manajemen dalam mengambil sebuah keputusan harus mendapat persetujuan penuh dari pemegang saham mayoritas. 


\section{Uji Parsial (uji t)}

Uji $t$ dalam penelitian ini dimaksudkan untuk mengetahui pengaruh secara parsial variabel independen terhadap variabel dependen. Ketentuan pengujian menggunakan tingkat signifikan sebesar 5\% (alpha=0,05) dan tingkat keyakinan sebesar 95\%. Dasar pengambilan keputusannya adalah sebagai berikut:

a. Jika nilai $t_{\text {hitung }}>t_{\text {tabel }}$ atau- $t_{\text {hitung }}<-t_{\text {tabel }}$ maka hipotesis alternatif yang menyatakan variabel independen secara parsial dan signifikansi mempengaruhi variabel dependen diterima.

b. Jika $t_{\text {hitung }}<t_{\text {tabel, }}$, maka hipotesis alternatif yang menyatakan variabel independen secara parsial dan signifikansi mempengaruhi variabel dependen ditolak.

Penelitian ini menggunakan tabel distribusi t dua ujung $(\alpha / 2)$ sehingga derajat bebasnya adalah:

$$
\text { Df } \quad \begin{aligned}
&=a / 2, n-k \\
&=0,025,120-3 \\
&=0,025,117
\end{aligned}
$$

Sehingga diperoleh nilai $t$ tabel sebesar $=1,980$

Tabel 8. thitung

\begin{tabular}{ccccccc}
\hline & & \multicolumn{2}{c}{ Unstandardized } & \multicolumn{2}{c}{$\begin{array}{c}\text { Standardized } \\
\text { Coefficients }\end{array}$} & \multicolumn{2}{c}{ Coefficients } & & \\
\cline { 3 - 4 } & Model & B & Std. Error & Beta & T & Sig. \\
\hline 1 & (Constant) &, 425 &, 095 & & 4,502 &, 000 \\
& ROE &, 659 &, 055 &, 746 & 12,018 &, 000 \\
& DER &, 214 &, 065 &, 206 & 3,322 &, 001 \\
\hline
\end{tabular}

Sumber: Output IBM Spss diolah (2021)

Berdasarkan tabel 8 dapat diketahui:

a. Berdasarkan tabel IV-9 ROE memperoleh $\mathrm{t}$ hitung 12,018 $>\mathrm{t}$ tabel sebesar 1,980 dengan nilai sig 0,000 $<0,05$ yang berarti bahwa $\mathrm{H}_{0}$ ditolak dan $\mathrm{H}_{1}$ yang menyatakan bahwa ROE berpengaruh tehadap nilai perusahaan diterima. Hasil penelitian ini sejalan dengan hasil penelitian Febriana (2013) dan Tjandakirana (2014).

b. Berdasarkan tabel IV-9 DER memperoleh $t$ hitung 3,322 $>\mathrm{t}$ tabel 1,980 dengan nilai sig $0,01<0,05 \mathrm{H}_{0}$ ditolak dan $\mathrm{H}_{2}$ yang menyatakan DER berpengaruh positif terhadap nilai perusahaan diterima. Penelitian ini sejalan dengan Sambora dkk (2014).

\section{Uji Determinasi ( $\left.\mathbf{R}^{2}\right)$}

Koefisien determinasi digunakan untuk menguukur besarnya kontribusi variabel independen terhadap variabel dependen, sehingga dapat diketahui variabel mana yang paling berpengaruh terhadap variabel independen. Nilai koefisien determinasi adalah antara 0 (nol) dan 1 (satu), $\mathrm{R}^{2}$ yang kecil atau mendekati 0 yang berarti kemampuan variabel independen dalam menjelaskan variasi variabel dependen terbatas, jika nilai $\mathrm{R}^{2}$ yang besar atau mendekati satu yang berati variabel independen memberikan hampir semua informasi yang dibutuhkan untuk memprediksi variasi variabel dependen. (Ghozali: 2011). 
Tabel 9. Hasil uji Determnasi

\begin{tabular}{ccccc}
\hline Model & $\mathbf{R}$ & R Square & Adjusted R Square & $\begin{array}{c}\text { Std. Error of the } \\
\text { Estimate }\end{array}$ \\
\hline 1 &, $746^{\mathrm{a}}$ &, 556 &, 545 &, 09953 \\
\hline Sumber: IBM SPSS 22 di oalah $(2021)$ & &
\end{tabular}

Berdasarkan tabel 9 dapat diketahui bahwa nilai Adjusted $R$ square sebesar 0,545 atau 54,5\% dalam menjelaskan variabel dependen. Artinya variabel independen secara bersama-sama dapat menjelaskan variabel dependen sebesar $54,5 \%$. Hal ini menunjukkan bahwa pengaruh ROE dan DER sebesar 54,5\% sedangkan 45,5\% ditentukan oleh fakor-faktor lainnya diluar model yang tidak terdeteksi atau diteliti dalam penlitian ini.

\section{Pengaruh ROE Terhadap Nilai Perusahaan}

Berdasarkan uji $\mathrm{t}$ ROE memperoleh nilai $\mathrm{t}$ hitung sebesar 12,018 $>\mathrm{t}$ tabel sebesar 1,980 dengan nilai sig 0,000 < 0,05 yang berarti H0 di tolak dan H1 diterima sehingga ROE berpengaruh positif dan signifikan terhadap nilai perusahaan yang di ukur dengan (PBV). Semakin tinggi nilai ROE maka semakin baik pula kondisi perusahaan, semakin besar pula penghasilan yang diperoleh perusahaan dan akan meningkatkan pula harga saham perusahaan yang bersangkutan.

Penelitian ini mendukung sinyal theory yang menyatakan bahwa sinyal yang diberikan dapat dilakukan dengan pengungkapan informasi akuntansi. Dalam hal ini informasi akuntansi merupakan ROE yang dimiliki oleh perusahaan akan dapat menjadi sinyal yang positif bagi investor dengan laba yang baik dapat meningkatkan kepercayaan investor publik terhadap manajemen perusahaan LQ 45 juga akan meningkat pula, secara otomatis akan mampu menguntungkan perusahaan. Semakin tinggi ROE menunjukkan prospek perusahaan LQ 45 semakin bagus, pembayaran deviden yang semakin meningkat dan para investor akan membeli saham di LQ 45, sehingga nilai saham meningkat dan nilai perusahaan akan naik. Penelitian ini sejalan dengan Su'aidah (2010), Thjandrakirana (2014), Ulul Fadilah (2014), Afidah (2014), Rita dkk (2018).

\section{Pengaruh DER terhadap Nilai Perusahaan}

Berdasarkan uji t DER memperoleh nilai thitung sebesar 3,322 > t tabel 1,980 dengan nilai sig 0,001 $<0,05 \mathrm{H}_{0}$ ditolak dan $\mathrm{H}_{2}$ diterima sehingga DER berpengaruh tehadap nilai perusahaan. Jadi semakin besar nilai DER maka semakin kecil laba yang akan dibagikan kepada pemegang saham, sehingga dapat menurunkan harga saham yang bersangkutan. Hasil penelitian ini sesuai dengan teory MM dengan pajak dimana struktur modal mempengaruhi nilai perusahaan. Perusahan dengan hutang yang tinggi mendapatkan penghematan pajak dari bunga yang dibayarkan sehingga nilai perusahaannya tinggi. Perusahaan tersebut dianggap memiliki keyakinan akan pertumbuhan perusahaan di masa yang akan datang. Penelitian ini sejalan dengan hasil penelitian Pratama \& Wirawati (2016), Agnes (2013) dan Chaidir (2015) yang membuktikan bahwa struktur modal yang diukur dengan DER berpengaruh positif dan signifikan terhadap nilai perusahaan. 


\section{Pengaruh Kepemilikan Manajerial dalam Memoderasi Hubungan ROE dengan Nilai Perusahaan}

Hasil pengujian hipotesis menunjukkan hasil uji interaksi antara variabel ROE dengan kepemilikan manajerial sebesar $0.000<0,05$ dan variabel pemoderasi memiliki arah negatif dilihat dari nilai koefisiennya $-0,331$. Variabel kepemilikan manajerial dapat memoderasi hubungan antara ROE terhadap nilai perusahaan dengan arah negatif. Nilai koefisien bertanda negatif, menunjukkan semakin tinggi kepemilikan manajerial maka kinerja keuangan akan semakin menurun dikarenakan pada perusahaan LQ 45 dengan adanya kepemilikan manajerial status manajer perusahaan sekaligus sebagai pemilik perusahaan, manajer mampu melakukan manipulasi laba untuk kepentingannya, sehingga bersifat oportunistik. Manajer akan cenderung melakukan tindakan atas kepentingan diri sendiri yang akan berdampak pada menurunnya nilai perusahaan dimata para pelanggan maupun investor. Karena tidak terjadi ketidaksamaan kepentingan antar manajer dengan pemilik yakni pemegang saham minoritas. Adanya kepemilikan manjerial kontrol antar pemilik dengan manajemen tidak optimal, sehingga dianggap mekanisme kontrol pemilik dengan manajemen tidak baik akan menimbulkan turunnya nilai perusahaan.

Manajer harus berhati-hati dalam mengambil keputusan karenan manajer juga ikut menanggung segala konsekuensi kemakmuran dari setiap tindakan maupun keputusan yang diambil. Oleh sebab itu kepemilikan manjaerial dalam suatu perusahaan maka mampu menjadi sinyal informasi terhadap suatu keputusan pendanaan perusahaan. Penelitian ini sejalan dengan Igede dkk (2016), Nimas (2017) dan Rita (2018).

\section{Pengaruh Kepemilikan Manajerial dalam Memoderasi Hubungan DER dengan Nilai Perusahaan}

Hasil hipotesis menunjukan hasil uji interaksi antara variabel DER dengan kepemilikan manajerial sebesar 0,190 >0,05 dan variabel moderasi memiliki nilai koefisien 0.228 sehingga menunjukan kepemilikan manajerial tidak mampu memoderasi hubungan antara DER dengan nilai perusahaan. Dengan kepemilikan manjerial yang relative rendah menyebabkan pihak manajemen tidak mempunyai wewenang penuh atas perusahaan. Sehingga manajemen dalam mengambil sebuah keputusan harus mendapat persetujuan penuh dari pemegang saham mayoritas. Pada perusahaan LQ 45 pada penelitian ini tingkat kepemilikan saham yang dimiliki manajer tidak mampu menyeimbangkan pendanaan, modal sendiri dan hutang, dimana ditunjukkan dengan tingginya DER yang berarti tingkat pendanaan melalui hutang pada perusahaan LQ 45 termasuk tinggi, oleh sebab itu kepemilikan manajerial tidak dapat memoderasi hubungan antara DER dengan nilai perusahaan. Ada tidaknya kepemilikan manajerial dalam suatu perusahaan tidak bisa dijadikan suatu informasi ataupun sinyal atas keputusan suatu pendanaaan, yang akan dilakukan oleh perusahaan. Karena presentase nilai kepemilikan manjerial pada suatu perusahaan yang masih rendah ataupun tidak terdapat kepemilikan manjerial. Hasil penelitian ini sejalan dengan penelitian yang dilakukan oleh Pratama dkk (2016), Fajriana dkk (2016) serta Ulfa dkk (2017) yang menyatakan bahwa kepemilikan manajerial 


\section{Simpulan}

Berdasarkan hasil analisis penelitian pengaruh ROE, DER terhadap nilai perusahaan dengan Kepemilikan Manajerial sebagai variabel moderasi periode 2016-2019 dapat ditarik kesimpulamn sebagai berikut:

a. Melalui penelitian ini diharapkan manajemen perusahaan dapat melihat faktor lain yang dapat memperkuat hubungan antara kinerja keuangan terhadap nilai perusahaan. Karena hal ini dapat mempengaruhi investor untuk menanamkan modalnya.

b. Perusahaan sebaiknya memperhatikan pengambilan keuangan yang baik sehingga dapat memberikan informasi yang akan meningkatkan nilai perusahaan, khususnya dalam menentukan proporsi ROE,DER dan tata kelola perusahaan yang dapat mempengaruhi nilai perusahaan.

c. Nilai perusahaan mencerminkan kinerja keuangan perusahaan yang dapat mempengaruhi persepsi investor terhadap perusahaan. Oleh karena itu investor yang ingin menanamkan modalnya pada perusahaan LQ 45 sebaiknya memperhatikan variabel-variabel ROE,DER serta tata kelola perusahaan sebagai bahan pertimbangan dalam pengambilan keputusan berinvestasi yang menguntungkan

\section{Referensi}

Asmoro, S. R., \& Fidiana, F. (2015). Struktur pendanaan dan pengaruhnya terhadap nilai perusahaan dengan kepemilikan manajerial sebagai pemoderasi. Jurnal Ilmu dan Riset Akuntansi (JIRA), 4(1).

Chaidir, C. (2015). Pengaruh Struktur Modal, Profitabilitas, Dan Pertumbuhan Perusahaan Terhadap Nilai Perusahaan Pada Perusahaan Sub Sektor Transportasi Yang Tercacat Di Bursa Efek Indonesia Periode 2012-2014. JIMFE| Jurnal Ilmiah Manajemen Fakultas Ekonomi, 2(2).

Fajriana, A., \& Priantinah, D. (2016). Pengaruh Corporate Social Responsibility, Keputusan Investasi, dan Struktur Modal Terhadap Nilai Perusahaan. Nominal: Barometer Riset Akuntansi dan Manajemen, 5(2), 16-28.

Ghozali, I. (2016). Aplikasi Analisis Multivariate dengan Program IBM SPSS 23. Edisi 8. Semarang: Badan Penerbit Universitas Diponegoro.

Halim, A. (2018). Analisis Investasi dan Aplikasinya dalam Asset Keuangan dan Asset Rill. Edisi 2. Jakarta: salemba Empat.

Halim, A. (2018). Analisis Investasi dan Aplikasinya: Dalam Aset Keuangan dan Aset Rill. Jakarta: Salemba Empat.

Hartono, J. (2009). Teori Portofolio dan Analisis Investasi. Yogyakarta: bpfeyogyakarta.

Husnan, S. (2014). Manajemen Keuangan Teori dan Penerapan (Keputusan Jangka Panjang). Edisi Keempat. Yogyakarta: BPFE. 
Kasmir. (2014). Analisis Laporan Keuangan. Cetakan ke tujuh. Edisi pertama. Jakarta: Raja Grafindo Persada.

Keown A. J. (2008). Manajemen Keuangan. Jakarta: PT Macan Jaya

Kusumaningrum, A. L. Pengaruh Kinerja Keuangan Terhadap Nilai Perusahaan dengan Kepemilikan Manajerial Sebagai Variabel Moderating (Studi pada Perusahaan Manufaktur yang Terdaftar di Bursa Efek Indonesia Periode 2012-2014). Skripsi. Universitas Jember

Kusumawati, R., \& Rosady, I. (2018). Pengaruh Struktur Modal dan Profitabilitas terhadap Nilai Perusahaan dengan Kepemilikan Manajerial sebagai Variabel Moderasi. Jurnal Manajemen Bisnis, 9(2), 147-160.

Mardiyanto, H. (2008). Intisari Manajemen Keuangan. Jakarta: Gasindo.

Ningrum, U. N. (2017). Pengaruh Kinerja Keuangan, Struktur Modal dan Ukuran Perusahaan Terhadap Nilai Perusahaan Dengan GCG dan CSR Sebagai Variabel Moderating Pada Perusahaan Peringkat Pertama ARA, ISRA dan Peringkat Emas Proper Yang Listing Di BEI Periode 2011-2015. Jurnal Ilmu Manajemen (JIM), 5(3).

Pratama, I., \& Wirawati, N. (2016). Pengaruh Struktur Modal dan Profitabilitas Terhadap Nilai Perusahaan dengan Kepemilikan Manajerial sebagai Pemoderasi. E-Jurnal Akuntansi Universitas Udayana, 15, 1796-1825.

Sawir, A. (2003). Analisis Kinerja Keuangan dan Perencanaam Keuangan Perusahaan. Jakarta: Gramedia Pustaka Utama.

Syafitri, T., Nuzula, N. F., \& Nurlaily, F. (2018). Pengaruh Good Corporate Governance Terhadap Nilai Perusahaan (Studi pada perusahaan industri sub sektor logam dan Sejenisnya yang terdaftar di bei periode 2012-2016). Jurnal Administrasi Bisnis, 56(1), 110-117. 